University of Nebraska - Lincoln

DigitalCommons@University of Nebraska - Lincoln

\title{
Lake sturgeon population attributes and reproductive structure in the Namakan Reservoir, Minnesota and Ontario
}

\author{
S. L. Shaw \\ South Dakota State University
}

S. R. Chipps

US Geological Survey, steven.chipps@sdstate.edu

Steve K. Windels

Voyageurs National Park, steve_windels@nps.gov

M. A. H. Webb

US Fish and Wildlife Service

Darryl T. McLeod

Ontario Ministry of Natural Resources, darryl.mcleod@ontario.ca

See next page for additional authors

Follow this and additional works at: https://digitalcommons.unl.edu/usgsstaffpub

Shaw, S. L.; Chipps, S. R.; Windels, Steve K.; Webb, M. A. H.; McLeod, Darryl T.; and Willis, D. W., "Lake sturgeon population attributes and reproductive structure in the Namakan Reservoir, Minnesota and Ontario" (2012). USGS Staff -- Published Research. 569.

https://digitalcommons.unl.edu/usgsstaffpub/569

This Article is brought to you for free and open access by the US Geological Survey at DigitalCommons@University of Nebraska - Lincoln. It has been accepted for inclusion in USGS Staff -- Published Research by an authorized administrator of DigitalCommons@University of Nebraska - Lincoln. 


\section{Authors}

S. L. Shaw, S. R. Chipps, Steve K. Windels, M. A. H. Webb, Darryl T. McLeod, and D. W. Willis 


\title{
Lake sturgeon population attributes and reproductive structure in the Namakan Reservoir, Minnesota and Ontario
}

\author{
By S. L. Shaw ${ }^{1}$, S. R. Chipps ${ }^{2}$, S. K. Windels ${ }^{3}$, M. A. H. Webb ${ }^{4}$, D. T. McLeod ${ }^{5}$ and D. W. Willis ${ }^{1}$ \\ ${ }^{1}$ Department of Natural Resource Management, South Dakota State University, Brookings, SD, USA; ${ }^{2}$ US Geological Survey, \\ South Dakota Cooperative Fish and Wildlife Research Unit, Department of Natural Resource Management, South Dakota State \\ University, Brookings, SD, USA; ${ }^{3}$ Voyageurs National Park, International Falls, MN, USA; ${ }^{4}$ US Fish and Wildife Service, \\ Bozeman Fish Technology Center, Bozeman, MT, USA; ${ }^{5}$ Ontario Ministry of Natural Resources, Fort Frances District, Fort \\ Frances, $O N$, Canada
}

\section{Summary}

Quantified were the age, growth, mortality and reproductive structure of lake sturgeon (Acipenser fulvescens) collected in the US and Canadian waters of the Namakan Reservoir. The hypotheses were tested that (i) age and growth of lake sturgeon in the Namakan Reservoir would differ by sex and reproductive stage of maturity, and (ii) that the relative strength of yearclasses of lake sturgeon in the reservoir would be affected by environmental variables. To quantify age, growth and mortality of the population, existing data was used from a multiagency database containing information on all lake sturgeon sampled in the reservoir from 2004 to 2009. Lake sturgeon were sampled in the Minnesota and Ontario waters of the Namakan Reservoir using multi-filament gillnets $1.8 \mathrm{~m}$ high and $30-100 \mathrm{~m}$ long and varying in mesh size from 178 to $356 \mathrm{~mm}$ stretch. Reproductive structure of the lake sturgeon was assessed only during spring 2008 and 2009 using plasma testosterone and estradiol-17 $\beta$ concentrations. Ages of lake sturgeon $>75 \mathrm{~cm}$ ranged from 9 to 86 years $(\mathrm{n}=533$, mean $=36$ years). A catch-curve analysis using the 19811953 year classes estimated total annual mortality of adults to be $4.8 \%$ and annual survival as $95.2 \%$. Using logistic regression analysis, it was found that total annual precipitation was positively associated with lake sturgeon year-class strength in the Namakan Reservoir. A $10 \mathrm{~cm}$ increase in total annual precipitation was associated with at least a $39 \%$ increase in the odds of occurrence of a strong year class of lake sturgeon in the reservoir. Plasma steroid analysis revealed a sex ratio of 2.4 females: 1 male and, on average, $10 \%$ of female and $30 \%$ of male lake sturgeon were reproductively mature each year (i.e. potential spawners). Moreover, there was evidence based on re-captured male fish of both periodic and annual spawning, as well as the ability of males to rapidly undergo gonadal maturation prior to spawning. Knowledge of lake sturgeon reproductive structure and factors influencing recruitment success contribute to the widespread conservation efforts for this threatened species.

\section{Introduction}

The lake sturgeon (Acipenser fulvescens) is a large, long-lived freshwater fish considered threatened throughout most of its range in North America (Harkness and Dymond, 1961; Bruch et al., 2009). Overharvest, habitat loss (spawning) and fragmentation (migration) have been implicated as factors influ- encing population declines in lake sturgeon (Priegel and Wirth, 1978; Auer, 1999). Because lake sturgeon mature at a late age and exhibit periodic spawning, information on age, growth and abundance is important for developing effective recovery and conservation plans (Brousseau, 1987; Scott and Crossman, 1998).

Construction of dams can have an important influence on lake sturgeon by blocking migration routes, altering spawning and nursery habitat, and changing natural flow regimes (Auer, 1996a,b). The Namakan Reservoir is a large system (approximately 26700 ha) located along the Minnesota-Ontario border. Since the early 1900 s, dams at the outlets of Rainy and Namakan lakes have prevented the upstream movement of lake sturgeon thus isolating these fish into three populations: Namakan Reservoir, Rainy Lake, and Rainy River / Lake of the Woods (Mosindy and Rusak, 1991; Adams et al., 2006). Previous lake sturgeon research in northern Minnesota and Ontario has been conducted in Rainy Lake (Adams et al., 2006), the Rainy River (Mosindy and Rusak, 1991; Stewig, 2005), and the lower Seine River, which is a tributary of Rainy Lake in Ontario (McLeod, 1999). However, little is known about the lake sturgeon population of the Namakan Reservoir - a large, complex system where future hydropower development is being proposed (McLeod, 2008).

In this study, we quantified age, growth, mortality and reproductive structure of lake sturgeon in the Namakan Reservoir. The hypotheses were tested that (i) age and growth of lake sturgeon in the Namakan Reservoir would differ by sex and reproductive stage of maturity, and (ii) that the relative strength of year-classes of lake sturgeon in the reservoir would be affected by environmental variables.

\section{Materials and methods}

Study area

The Namakan Reservoir is a complex system located along the Minnesota-Ontario border (Fig. 1). It lies downstream of the Boundary Waters Canoe Area Wilderness and Quetico Provincial Park and upstream of Rainy Lake. The water in this system flows northwest from the Namakan Reservoir into Rainy Lake, Rainy River and then Lake of the Woods. The Namakan Reservoir has a surface area of approximately $260 \mathrm{~km}^{2}$ and a water residence time of about 235 day (Kallemeyn et al., 2003). It includes five water bodies: Kabetogama, Namakan, Sand Point, Crane and Little Vermilion lakes, and their associated 


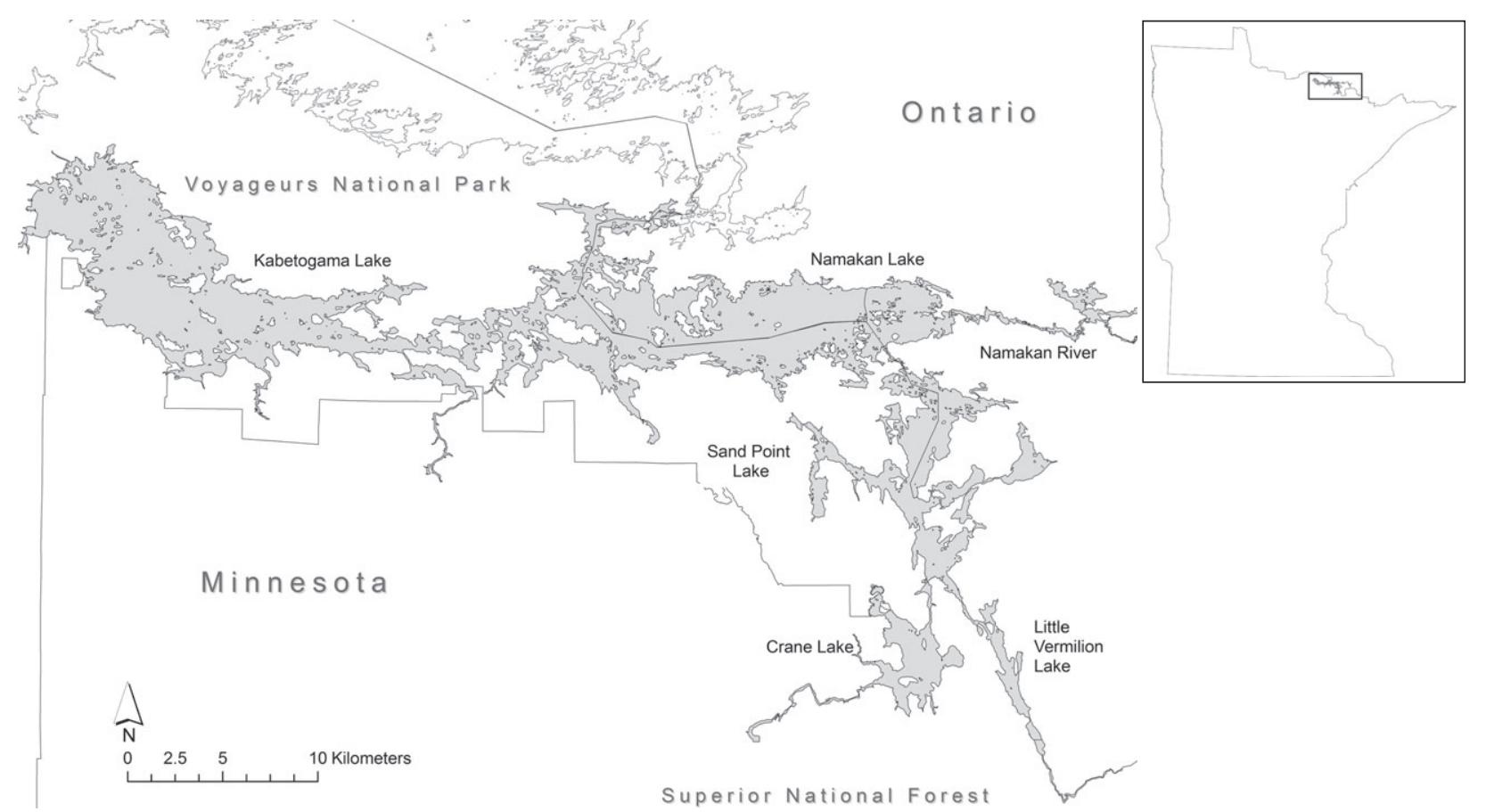

Fig. 1. Map of study area, Namakan Reservoir, Minnesota-Ontario border. All five lakes included within the reservoir complex are in grey. The South Arm of Rainy Lake (white) is visible adjoining Namakan Reservoir at the most northern section of Namakan Lake

tributaries. The Namakan Reservoir includes the largest source of inflow to the Voyageurs National Park system, the Namakan River, which has a mean discharge of $109 \mathrm{~m}^{3} \mathrm{~s}^{-1}$ (Kallemeyn et al., 2003). The maximum depth of $56.1 \mathrm{~m}$ is in Sand Point Lake (Kallemeyn et al., 2003). Four of the five lakes that make up the Namakan Reservoir are classified as dimictic with a stable stratification throughout the warm season and mixing only occurring before and after the period of seasonal ice cover (Kallemeyn et al., 2003). Kabetogama Lake, the shallowest lake in the reservoir, can be described as discontinuous cold polymictic (Kallemeyn et al., 2003). The Minnesota-Ontario border traverses Namakan, Sand Point and Little Vermilion lakes. Voyageurs National Park, established in 1975, encompasses Kabetogama Lake and the US waters of Namakan and Sand Point lakes. The Superior National Forest borders Crane and Little Vermilion lakes on the US side of the border. Water levels have been regulated by the International Joint Commission (IJC) through the International Rainy Lake Board of Control (IRLBC) since 1949 (Kallemeyn et al., 2003; McLeod and Debruyne, 2009). Upon the creation of the park in 1975, the water was regulated under the 1970 Supplementary Order, which resulted in unnatural fluctuations in water levels for both the Namakan Reservoir and Rainy Lake. Under this order the Namakan Reservoir experienced larger-than-natural water levels fluctuations and Rainy Lake less-than-natural fluctuations, which was found to adversely affect many species and biological communities (Kallemeyn et al., 2003). As a result, the IJC implemented in 2000 a hydrologic management regime that more closely resembles natural flows for the Namakan Reservoir (Kallemeyn et al., 2003).

\section{Lake sturgeon collection}

Multiple agencies working on the Namakan Reservoir collaborate to conduct annual spring pre-spawn sampling of lake sturgeon. The same data is collected by each agency and contained in one cooperative database (J. Eibler, Minnesota
Department of Natural Resources; D. McLeod, Ontario Ministry of Natural Resources). We used existing data from this database to quantify age, growth and mortality of lake sturgeon. In short, lake sturgeon were collected in the spring, beginning shortly after ice-out and ending prior to the onset of optimum lake sturgeon spawning temperatures $\left(13^{\circ} \mathrm{C}\right.$; Harkness and Dymond, 1961). Biologists from Voyageurs National Park, the Ontario Ministry of Natural Resources (OMNR), Minnesota Department of Natural Resources, the US Forest Service and the US Geological Survey all participated in lake sturgeon collection. The Ontario Ministry of Natural Resources conducted additional sampling in autumn of 20052008, concentrating efforts in the Namakan River. Lake sturgeon were collected by all agencies using multifilament gillnets $(178,203,230,254,305$ and 356-mm stretch meshes) $1.8 \mathrm{~m}$ high and 30-100 $\mathrm{m}$ long set throughout the system. All lake sturgeon were measured for total length, fork length, and girth $(\mathrm{mm})$, and then weighed on a hand scale $(\mathrm{kg})$. A $2-3 \mathrm{~cm}$ section of the pectoral fin spine was obtained for age determination. Each lake sturgeon was tagged with a uniquely numbered Carlin disc tag.

\section{Age and growth}

Sections of the pectoral fin spine were used to determine age of lake sturgeon. Fin spine sections were air dried for at least 4 weeks and two $0.5 \mathrm{~mm}$ sections were cut from the proximal end using an Isomet saw (model 11-1280-160, Buehler). Age was estimated by imaging the fin spine cross-sections using an Olympus Model SZX16 stereo microscope. Spine crosssections were aged independently by two viewers from South Dakota State University. Ages were cross-validated by sending a subset of cross-section images to two fisheries biologists experienced in lake sturgeon aging (W. E. Adams, Jr., South Dakota Department of Game, Fish and Parks, Pierre, South Dakota and S. Mann, OMNR, Dryden, Ontario). 
The growth increments on pectoral fin spines of lake sturgeon are difficult to differentiate during periods of slowed growth, which increase in frequency with age. Bruch et al. (2009) found that pectoral fin spines underestimate the age of lake sturgeon older than 14 years. As a result, we adjusted ages of fish using the equation developed by Bruch et al. (2009):

Adjusted age $=[\text { estimated age }]^{1.055}$.

We applied this correction to all lake sturgeon 15 years of age and greater.

\section{Year-class strength}

Year-class strength of lake sturgeon was quantified using the residual method described by Maceina (2003). Year-class strength was indexed by calculating the residuals from a catchcurve analysis. We used a weighted regression in the catchcurve analysis to deflate the influence of the older and (or) rarer year-classes (Maceina and Pereira, 2007). Stronger yearclasses were associated with positive residual values whereas weaker year-classes were associated with negative residuals. Fishery analyses and simulation tools (FAST; Slipke and Maceina, 2000) software were used to calculate both the catchcurve residuals and the total annual mortality rate using the weighted (by number) regression option.

Climate data on mean monthly air temperature (1885-2006) were obtained from the National Oceanic and Atmospheric Administration, International Falls Station. As air temperature was found to be correlated with surface water temperature (McCombie, 1959; Magnuson et al., 1990), and historic water temperature data were unavailable, mean air temperature was used as an indicator of mean water temperature. The mean air temperature was calculated for each season. Seasons were defined based on the dates of yearly solstices and equinoxes (20 March, 21 June, 22 September, and 21 December). Hydrologic data (1941-2009) were obtained from the Lake of the Woods Control Board and included total annual precipitation (cm; 1885-2006), mean spring (20 March to 20 June) water elevation (m), and weekly inflow and daily outflow discharge data $\left(\mathrm{m}^{3} \mathrm{~s}^{-1}\right)$. Mean inflow and outflow data were calculated for each season. Ice-out dates prior to 1980 from the Namakan Reservoir were unavailable, therefore ice-out dates (1930-2009) from Rainy Lake, the reservoir immediately downstream of the Namakan Reservoir, were obtained from the Ontario Ministry of Natural Resources (D. McLeod, unpubl. data). Annual ice-out dates were defined ordinally, where 1 January was equal to the date 001 and 31 December was equal to 365 .

To test the hypothesis that year-class strength of lake sturgeon is linked to environmental variation, we evaluated the influence of climatologic and hydrologic variation on yearclass strength using logistic regression analysis (PROC LOGISTIC; SAS@ Institute Inc, 1999). Plotting the frequency distribution of residual values revealed a distribution that was strongly skewed to the right, with most strong year-classes (i.e. positive residual values) occurring in the upper 33\% of the frequency distribution. Because of [unknown] error associated with using pectoral fin spines to determine exact ages of adult lake sturgeon, we grouped 'strong' year-classes as those that had residual values in the upper $33 \%$ of the distribution. Average (or weak) year-classes were characterized by low (positive) or negative residual values in the lower $67 \%$ of the distribution. For modeling purposes, a value of ' 1 ' was assigned to strong year-classes and a value of ' 0 ' to others.
We tested the odds of occurrence of a strong lake sturgeon year-class against all climatologic and hydrologic variables. The Hosmer-Lemeshow goodness-of-fit test $(\mathrm{P}>0.05)$ was used to assess how well the global logistic model met the assumptions underlying logistic regression (Hosmer and Lemeshow, 1989; Rich et al., 2003). Odds ratios, calculated as e raised to the $i$ th logistic regression coefficient (e.g. $\mathrm{e}^{\hat{\beta}}$.), were used to evaluate the importance of each variable in the model. Because odds ratios are based on a single unit change, a scaling factor (C) was calculated for each variable to establish a unit of change that would be biologically relevant (Rich et al., 2003). The scaling factor was determined by taking the difference in the median value (of climate and hydrologic variables) between strong (value $=1$ ) and weak (value $=0$ ) year-classes and rounding to the nearest unit of five. The scaled odds ratio was then calculated as $\mathrm{e}^{C \cdot \hat{\beta}_{i}}$ to reflect a more meaningful change in the magnitude of the variable (Rich et al., 2003). The 95\% confidence interval of each significant variable was used to evaluate the biological significance of the value at the lower (positive coefficient) and upper (negative coefficient) bounds. Confidence intervals were calculated for the scaled odds ratio as $\mathrm{e}^{C \cdot \hat{\beta}_{i} \pm Z 0.975 \cdot C \cdot \operatorname{SE}(\hat{\beta})}$ where $z_{0.975}=1.961$ (Rich et al., 2003).

\section{Reproductive attributes}

In spring 2008 and 2009, blood ( $2 \mathrm{ml}$ ) was collected from the caudal vasculature of pre-spawning lake sturgeon $(\mathrm{N}=136)$ using heparinized syringes ( $3 \mathrm{cc}, 23$ gauge, $38 \mathrm{~mm}$ needle). Samples were stored on wet ice and processed within $1 \mathrm{~h}$ of collection by centrifuging at $2000 \mathrm{~g}$ for $10 \mathrm{~min}$ at room temperature. The steroids, testosterone $(\mathrm{T})$ and estradiol-17ß (E2), were extracted from plasma and analyzed by radioimmunoassay (RIA; Fitzpatrick et al., 1987; Webb et al., 2002). Briefly, $100 \mu \mathrm{l}$ of plasma was extracted twice with $2 \mathrm{ml}$ of diethyl ether. Tubes were vortexed vigorously with ether, and the aqueous phase was removed by snap-freezing in liquid nitrogen. Combined extracts were dried in a Speed Vac centrifuge, resuspended in $1 \mathrm{ml}$ of phosphate-buffered saline with gelatin (PBSG), and 10 or $50 \mu$ were assayed for each steroid. Recovery efficiencies for all steroids were determined by adding tritiated steroids to tubes containing plasma $(n=4)$, which were extracted as described above. The average recovery efficiencies for $\mathrm{T}$ and $\mathrm{E} 2$ were 94 and $75 \%$, respectively. All steroid assay results were corrected for recovery. All samples were analyzed in duplicate. The lowest quantifiable concentration for both $\mathrm{T}$ and $\mathrm{E} 2$ was $0.20 \mathrm{ng} \mathrm{ml}^{-1}$. The intraand inter-assay coefficients of variation for all assays were $<5$ and $10 \%$, respectively.

Sex and stage of maturity was assigned to each lake sturgeon based on plasma $\mathrm{T}$ and E2 concentrations using methods outlined in Webb et al. (2002). To test the null hypothesis that there is no difference in mean total length (TL), weight or age between male and female lake sturgeon in the Namakan Reservoir these variables were compared using a $t$-test with Bonferroni correction for multiple comparisons. Female lake sturgeon were classified into three reproductive groups: previtellogenic, vitellogenic and post-vitellogenic (Webb et al., 2002; Webb and Erickson, 2007; Allen et al., 2009). Both E2 and $\mathrm{T}$ concentrations were used in the classification of females into potential reproductive stage. Sturgeon with the lowest concentrations of E2 (e.g. non-detectable or $<0.20 \mathrm{ng} \mathrm{ml}^{-1}$ ) and low $\mathrm{T}\left(<3.0 \mathrm{ng} \mathrm{ml}^{-1}\right)$ were classified as pre-vitellogenic. Sturgeon with relatively low $\mathrm{T}\left(>1.5\right.$ and $\left.<15.0 \mathrm{ng} \mathrm{ml}^{-1}\right)$ and moderate to high levels of E2 $\left(>0.20\right.$ and $\left.<9.0 \mathrm{ng} \mathrm{ml}^{-1}\right)$ were 
classified as vitellogenic. The post-vitellogenic stage had relatively high levels of both $\mathrm{E} 2$ and $\mathrm{T}\left(\mathrm{E} 2>2.0 \mathrm{ng} \mathrm{ml}^{-1}\right.$ and $\mathrm{T}>18.0 \mathrm{ng} \mathrm{ml}^{-1}$ ). These sturgeon correspond to gravid females that would be capable of reproducing in the season they were sampled. We compared mean total length, weight and girth among pre-vitellogenic, vitellogenic, and post-vitellogenic females using a single factor ANOvA with Bonferroni Correction (Webb and Erickson, 2007). The hypothesis was tested that there would be no difference in mean total length, weight, or girth among reproductive stages of female lake sturgeon in the Namakan Reservoir. Similarly, male lake sturgeon were classified into three reproductive groups based on plasma T levels: mitotic, meiotic and spermiating. Males with the elevated $\mathrm{T}$ levels $\left(>30 \mathrm{ng} \mathrm{m}^{-1}\right.$ ) were considered spermiating fish and capable of reproduction in the year sampled (Webb and Erickson, 2007). A single factor ANOvA with Bonferroni Correction was used to compare size characteristics among mitotic, meiotic, and spermiating male lake sturgeon (Webb and Erickson, 2007). Multiple comparison tests were performed using a Tukey's Studentized range test. We tested the hypothesis that there is no difference in size characteristics among male lake sturgeon at differing stages of gonadal maturation in the Namakan Reservoir.

\section{Results}

\section{Age and growth}

A total of 663 lake sturgeon were collected from 2004 to 2009 in US and Canadian waters of the Namakan Reservoir (including the Namakan River). The total length of lake sturgeon ranged from 77.4 to $174.6 \mathrm{~cm}$ (mean $=124.5 \mathrm{~cm}$ ). Lake sturgeon weight (W) was positively related to total length (TL) as,

$\log _{10} \mathrm{~W}=-6.145+3.448\left(\log _{10} \mathrm{TL}\right)$

(log-log linear regression, $\left.\mathrm{n}=506, \mathrm{P}<0.0001, r^{2}=0.92\right)$.

Of the 663 lake sturgeon collected, 533 were successfully aged using pectoral fin spines. The remaining 130 sturgeon were not aged due to the fact that either pectoral spines were not collected at the time of sampling or spine cross-sections were of insufficient quality to age reliably. Ages of lake sturgeon ranged from 9 to 86 years, with a mean age of 36 . The age distribution was represented by the 1923-1999 year-classes with $75 \%$ of lake sturgeon from the 1953 to 1981 year classes (Fig. 2).

Catch data was used for 28- to 56-year-old lake sturgeon (1981-1953 year classes) to conduct the catch-curve analysis (Fig. 3). The 1981 year-class was the first year-class considered fully recruited to the gear. When using a catch-curve approach to estimate mortality rate, including the oldest (e.g. rarest) individuals can complicate the analysis. Therefore, we followed the approach outlined by Miranda and Bettoli (2007), and truncated the age distribution by considering only the oldest age group with at least five individuals - in this case, the 1953 year-class. Using this approach, total annual mortality was estimated at $4.8 \%$, and total annual survival was $95.2 \%$. The most abundant (strongest) year-classes occurred between 1963 and 1972 (ages 46-37). Weak year-classes were particularly evident in 1974 (age 35), 1959 (age 50) and 1957 (age 52; Fig. 3).

\section{Year-class strength}

A total of 15 variables was included in the logistic regression analysis, total annual precipitation, spring water elevation, ordinal ice-out date, and seasonal means ( $\mathrm{n}=4$ seasons) for air temperature, mean inflow and mean outflow. Using a stepwise forward regression model, a variable was excluded from the model fit if it did not meet the entry-level significance value of 0.05 . Total annual precipitation and mean autumn air temperature were the only significant variables included in the final model (Table 1). The Hosmer-Lemeshow Goodness of fit results $\left(\mathrm{P}>\chi^{2}=0.58\right.$, d.f. $\left.=8, \chi^{2}=6.65\right)$ showed that the model provided a reasonable $(\mathrm{P}>0.05)$ fit for the data.

Total annual precipitation was positively associated with year-class strength (Table 1). A $10 \mathrm{~cm}$ increase in total annual precipitation was associated with at least a $39 \%(1.39 / 1)$ increase in the odds of occurrence of a strong year-class of lake sturgeon. In contrast, mean autumn air temperature was negatively associated with year-class abundance (Table 1). A $3^{\circ} \mathrm{C}$ increase in mean autumn air temperature was associated with about an $8 \%(1 / 0.93)$ decrease in the odds of occurrence of a strong lake sturgeon year-class.

\section{Reproductive attributes}

Plasma T and E2 concentrations were analyzed from 133 prespawning lake sturgeon collected in 2008 and 2009. Classification of fish using steroid concentrations revealed 94 females and 39 males (Fig. 4). Females were significantly longer and heavier than males (Table 2). There was also a difference in age

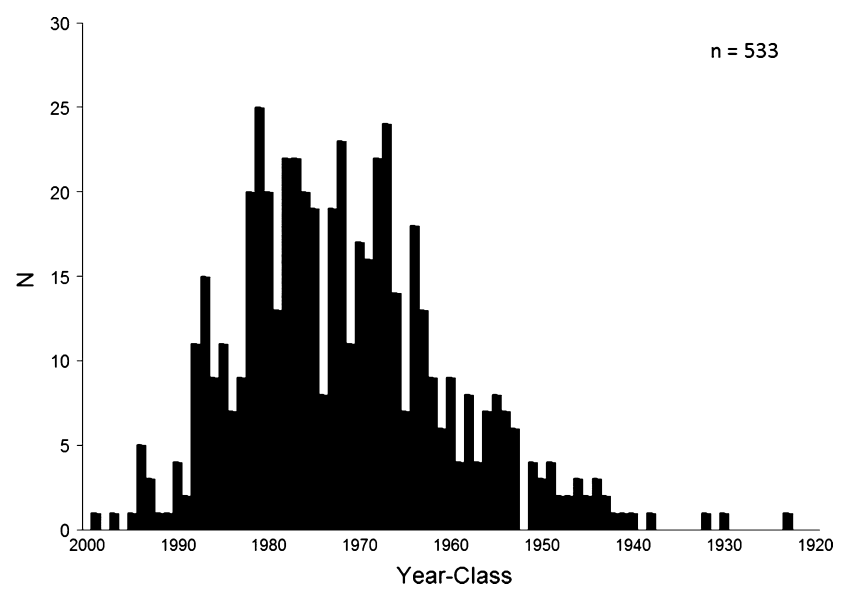

Fig. 2. Frequency distribution of year-classes for lake sturgeon (sexes combined) collected from Namakan Reservoir, 2006-2009

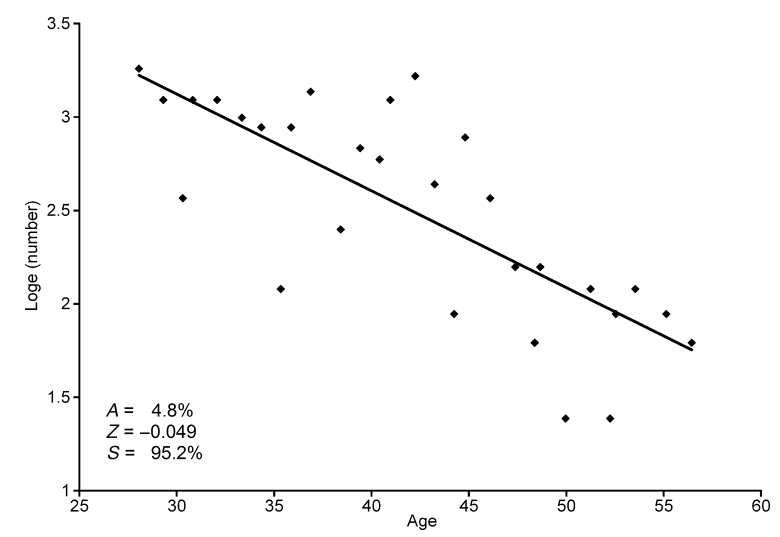

Fig. 3. Abundance ( $\log _{\mathrm{e}}$ total catch) of lake sturgeon (ages 28-56) collected from Namakan Reservoir, 2006-2009 (regression analysis, $\left.\mathrm{n}=30, r^{2}=0.57, \mathrm{P}<0.0001\right)$. Catch curve analysis (FAST software) was used to estimate annual mortality (A), instantaneous mortality (Z), and annual survival (S) 
Table 1

Logistic model variables for predicting occurrence of a strong lake sturgeon year-class

\begin{tabular}{lcccccc}
\hline Variable & DF & $\begin{array}{l}\text { Parameter } \\
\text { estimate }\end{array}$ & $\begin{array}{l}\text { Standard } \\
\text { error }\end{array}$ & $\begin{array}{l}\text { Scaling } \\
\text { factor }\end{array}$ & $\begin{array}{l}\text { Scaled odds } \\
\text { ratio }\end{array}$ & $\begin{array}{l}95 \% \text { CI for scaled } \\
\text { odds ratio }\end{array}$ \\
\hline Intercept & 1 & -16.75 & 5.49 & & & 0.0099 \\
Total Annual Precipitation $(\mathrm{cm})$ & 1 & 0.19 & 0.079 & 10 & 6.69 & $(1.39,32.07)$ \\
Mean Autumn Air Temperature $\left({ }^{\circ} \mathrm{C}\right)$ & 1 & -0.75 & 0.37 & 3 & 0.11 & $(0.012,0.93)$ \\
\hline
\end{tabular}

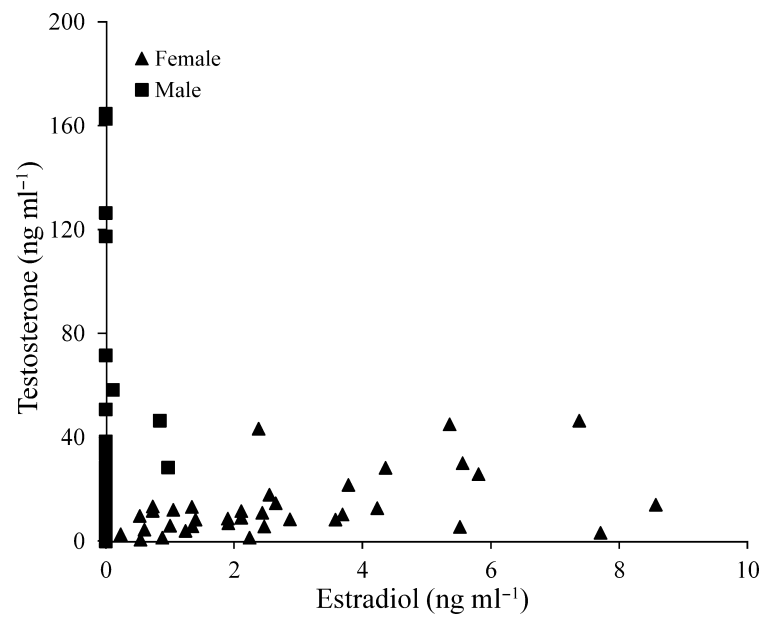

Fig. 4. Plasma steroid concentrations (testosterone and estradiol-17 $\beta$ ) of male $(\mathrm{n}=39)$ and female $(\mathrm{n}=94)$ lake sturgeon collected from Namakan Reservoir, spring 2008 and 2009. Spring sampling started each year shortly after ice-out and continued until water temperatures approached optimum lake sturgeon spawning temperatures $\left(13^{\circ} \mathrm{C}\right.$ Harkness and Dymond, 1961). [Correction Statement: The diagram of Fig. 4 has been replaced after initial online publication on 6 February 2012]

between males and females, with females (mean 47 years, range 9-86 years) being significantly older than males (mean 40 years, range 19-66 years; $\mathrm{P}_{r}>F=0.005$, d.f. $=120$, $F=8.41)$.

A total of 11 males, five in 2008 and six in 2009, were classified as spermiating (ripe) fish, corresponding to an average of $30 \%$ of the males sampled each year (Fig. 5). There was no difference in mean total length, mean weight or mean girth among reproductive stages in males (Table 2).

A total of eight females, four each in 2008 and 2009, were classified as post-vitellogenic (gravid), which corresponded to an average of $9.5 \%$ of the females sampled each year (Fig. 6). Moreover, mean size of females differed among reproductive stages. Gravid females were significantly larger than previtellogenic females in mean total length, mean weight, and mean girth (Table 2). Mean weight of gravid females was also significantly higher than for vitellogenic females, but other size characteristics were similar. Vitellogenic females were larger than pre-vitellogenic females in mean weight and mean girth (Table 2).

\section{Discussion}

Low annual mortality $(4.8 \%)$ of adult lake sturgeon in the Namakan Reservoir indicates that year-class strength is likely determined at the larval or juvenile stage of development, congruent with other studies (Richmond and Kynard, 1995; Nilo et al., 1997). No year-classes from 1953 to 1981 were missing, indicating relatively consistent recruitment patterns for lake sturgeon. Moreover, the size and age distribution of lake sturgeon in Namakan Reservoir was similar to those reported for other North American lake sturgeon populations (Fortin et al., 1996).

Annual variation in environmental conditions is known to influence growth and survival of sturgeon during their first year of life (Lebreton and Beamish, 2004). We found a positive relationship between lake sturgeon year-class strength and total annual precipitation in the Namakan Reservoir. Lake water levels generally increase in years with higher precipitation (Goldman and de Amazaga, 1984) and could provide increased spawning and nursery habitat for lake sturgeon that enhance year-class strength (i.e. better spawning and rearing conditions; Kohlhorst et al., 1991). In a study of Siberian sturgeon, Acipenser baerii, year-class strength was directly related to water levels in the Ob River, USSR (Votinov and Kas'yanov, 1978). Similarly, increased water flow in the St. Lawrence system was positively related to year-class strength for lake sturgeon (Nilo et al., 1997). Long-term studies in Lake Tahoe, California indicated that percent change in primary productivity was positively correlated to annual precipitation (Goldman and de Amazaga, 1984; Goldman, 1988).

Seasonal water temperature can be an important factor affecting growth, survival and year-class strength in sturgeon (Khoroshko, 1972; Nikol'skaya and Sytina, 1978; Fortin et al.,

Table 2

Mean total length (TL), mean weight (WT) and mean girth $(\mathrm{G})$ compared by sex and within each sex by reproductive stage for lake sturgeon collected in Namakan Reservoir, 2008 and 2009. For length, weight, and girth comparisons of lake sturgeon by sex and within each sex by stages, values with the same letter are not significantly different $(\mathrm{P}>0.05)$. Sex was predicted using plasma steroid concentrations

\begin{tabular}{|c|c|c|c|c|c|}
\hline Sex & Reproductive stage & $n$ & Mean total length (mm) & Mean weight (kg) & Mean girth (mm) \\
\hline Female & All stages & 94 & $1335(832-1715) \mathrm{a}$ & $16.23(5.0-35.0) \mathrm{a}$ & $47(9-86) \mathrm{a}$ \\
\hline Male & All stages & 39 & $1257(1005-1650) b$ & $13.83(6.0-36.0) \mathrm{b}$ & $40(19-66) b$ \\
\hline \multirow[t]{3}{*}{ Female } & Pre-vitellogenic & 60 & $1298(832-1639) a$ & $14.0(5.4-28.5) \mathrm{a}$ & $482(327-598) a$ \\
\hline & Vitellogenic & 26 & $1371(1145-1715) a b$ & $18.8(12.0-35.0) \mathrm{b}$ & 538 (415-699)a \\
\hline & Post-vitellogenic & 8 & $1490(1410-1534) b$ & $24.3(17.0-31.1) \mathrm{c}$ & $591(525-658) b$ \\
\hline \multirow[t]{3}{*}{ Male } & Mitotic & 21 & $1232(1100-1442) a$ & $12.5(6.0-22.0) \mathrm{a}$ & 469 (397-595)a \\
\hline & Meiotic & 7 & $1258(1166-1344) \mathrm{a}$ & $12.8(10.2-15.5) \mathrm{a}$ & 467 (417-530)a \\
\hline & Spermiating & 11 & $1308(1005-1650) a$ & $17.2(8.5-36.0) \mathrm{a}$ & $510(364-728) a$ \\
\hline
\end{tabular}




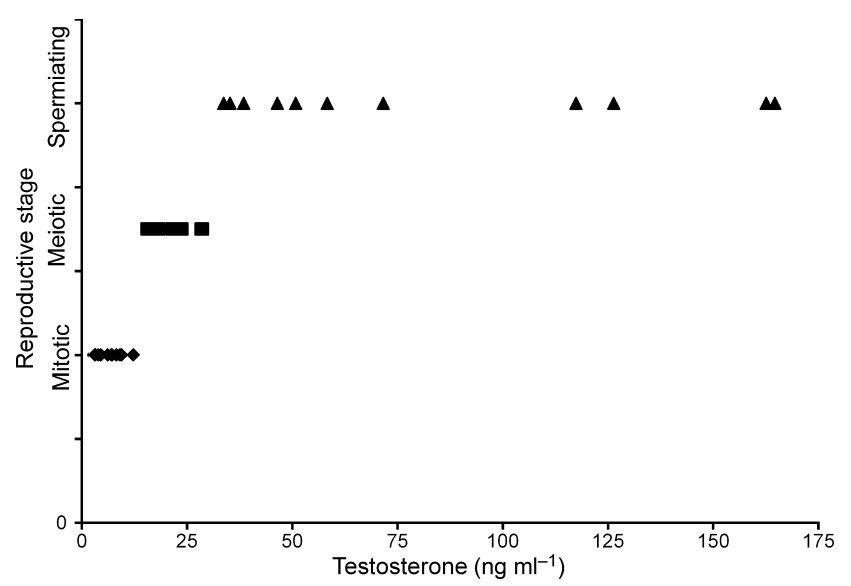

Fig. 5. Plasma testosterone concentration of male lake sturgeon $(\mathrm{n}=39)$ classified into three reproductive stages, Namakan Reservoir, spring 2008 and 2009

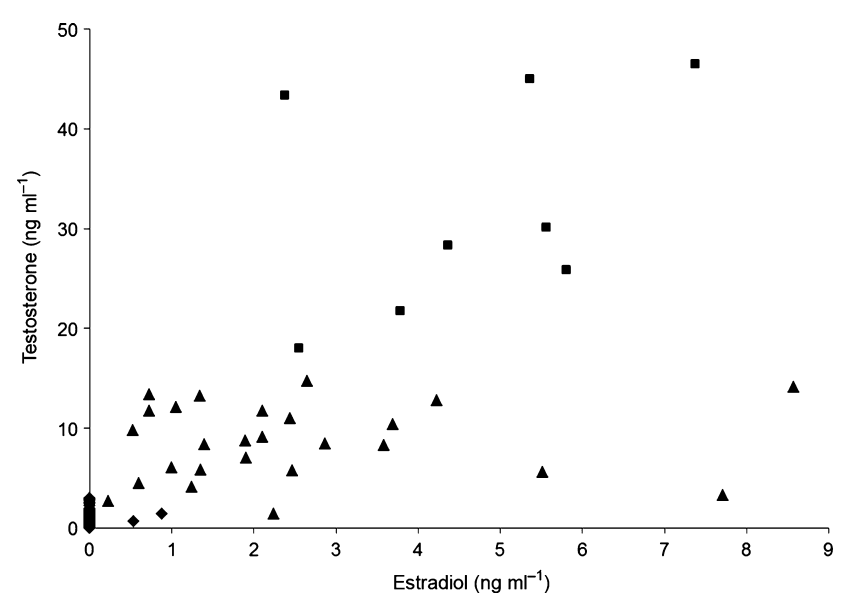

Fig. 6. Plasma estradiol-17 $\beta$ and testosterone concentration of female lake sturgeon $(\mathrm{n}=94)$ collected from Namakan Reservoir, spring 2008 and 2009. Females were classified into one of three reproductive stages following Webb et al. (2002). Symbols represent: pre-vitellogenic, vitellogenic, and post-vitellogenic fish

1996; Nilo et al., 1997; Power and McKinley, 1997). We found that mean autumn air temperature was negatively related to lake sturgeon year-class strength in the Namakan Reservoir. The reason for this is not clear. One explanation may be related to a reduced activity and (or) increased energetic efficiency at cooler water temperatures. Telemetry studies indicate that lower autumn water temperatures are associated with decreased movement rates of adult lake sturgeon (HayChmielewski, 1987; Mosindy and Rusak, 1991; McLeod and Debruyne, 2009). Decreased activity combined with lower energetic costs may result in a growth advantage for juvenile lake sturgeon during autumn. Other factors, such as food quality and availability, also vary with seasonal changes in water temperature and lake productivity, and may influence growth and overwinter survival for juvenile fishes (Shuter and Post, 1990).

Female lake sturgeon, classified by circulating plasma steroid concentrations, represented $71 \%$ of the total catch, which was within the range (68-95\%) reported for other populations (Threader and Brousseau, 1986; Auer, 1999). Female lake sturgeon are known to reach larger sizes than males (Probst and Cooper, 1955; Mosindy and Rusak, 1991).
Thus, females may be more vulnerable to the sampling gear than males and make up a larger proportion of the lake sturgeon sampled. Therefore it is possible that our sex ratio estimate is biased toward larger lake sturgeon and therefore toward females. Female lake sturgeon also live longer than males, which coupled with the low annual mortality of adult fish $(4.8 \%)$, may lead to a larger proportion of females present in the population (Probst and Cooper, 1955; Mosindy and Rusak, 1991).

Adult male lake sturgeon generally exhibit a 2- to 4-year reproductive cycle and evidence of annual spawning has not been well documented (Auer, 2004). Plasma T concentrations from male lake sturgeon in Namakan Reservoir indicated that the majority of fish sampled in both years were characterized by a non-reproductive stage of gonadal development, while $30 \%$ of the males had elevated concentrations of $\mathrm{T}$, suggesting late gametogenesis and a 3-year reproductive cycle. However, one male fish captured each year during the 2 years that blood samples were collected was classified as ripe in 2008 and 2009. Although reportedly not common (Auer, 1999), annual reproduction by male lake sturgeon is physiologically possible, although likely exhibited by only a small fraction of adult males.

The annual proportion of ripe males $(30 \%)$ found in our study may be a conservative estimate. In 2009, a male captured twice in a 3-day span exhibited the ability to rapidly increase $\mathrm{T}$ levels and potentially mature from a non-reproductive to a reproductive stage of development prior to the spawn. The first collection was on 5 May 2009, at which time the fish was determined as being in a non-reproductive, meiotic stage of gonadal development $\left(\mathrm{T}=23.84 \mathrm{ng} \mathrm{ml}^{-1}\right)$. The same sturgeon was sampled again on 7 May 2009 in the same location; the plasma $\mathrm{T}$ concentration had increased indicating the fish may have matured to a spermiating or ripe gonadal stage $\left(\mathrm{T}=35.21 \mathrm{ng} \mathrm{ml}^{-1}\right)$. Although we were unable to confirm the maturation with a tissue sample, this sturgeon was collected upstream in a tributary of the reservoir near a potential spawning location supporting the idea that it was exhibiting spawning behavior. The ability of male lake sturgeon to undergo a rapid gonadal maturation prior to the spawn means that our estimate of the proportion of males that are capable of spawning in any given year is likely low and also suggests a faster gametogenic cycle.

Currently, the Namakan Reservoir supports a viable population of lake sturgeon characterized by low total annual mortality, consistent recruitment, and an age and size distribution similar to other North American populations. A sex ratio skewed toward females may be countered by a shorter spawning periodicity of males. Thus, a larger proportion of the male population is capable of reproduction during the spawning season. It may also indicate a gear bias whereby larger lake sturgeon were more vulnerable to our sampling methods. The reproductive stage of development as well as the proportions of both males and females capable of reproducing in each spawning season has important implications for evaluating reproductive structure and conservation strategies for this protected species.

\section{Acknowledgements}

We thank T. Brezden, T. Burri, J. Butcher, C. Debruyne, J. Eibler, M. Fincel, B. Flatten, K. Gebhardt, C. Glase, J. Glase, B. Halliday, B. Henning, P. Hogan, D. James, L. Kallemyn, M. Lebron, D. Lilja, B. McLaren, H. Meyer, M. Moseley, 
W. Nixon, A. Rob, L. Schultz, C. Sundmark, M. Thul, and C. Trembath, for technical assistance in the field, and E. Cureton at the Bozeman Fish Technology Center for analysis of sex steroid concentrations. G. Adams and S. Mann assisted with age-analysis of lake sturgeon. Funding for this project was provided by the National Park Service (CESU Agreement J6820081161). The USGS South Dakota Coop Unit is jointly supported by the US Geological Survey, South Dakota Department of Game, Fish and Parks, South Dakota State University, and the Wildlife Management Institute. Any use of trade names is for descriptive purposes only and does not imply endorsement by the US Government.

\section{References}

Adams, W. E., Jr; Kallemeyn, L. W.; Willis, D. W., 2006: Lake sturgeon population characteristics in Rainy Lake, Minnesota and Ontario. J. Appl. Ichthyol. 22, 97-102.

Allen, P. J., Webb, M. A. H., Cureton, E.; Bruch, R. M.; Barth, C. C.; Peake, S. J.; Anderson, W. G., 2009: Calcium regulation in wild populations of a freshwater cartilaginous fish, the lake sturgeon Acipenser fulvescens. Comp. Biochem. Physiol. Part A Mol. Integr. Physiol. 154, 437-450.

Auer, N. A., 1996a: Response of spawning lake sturgeon to change in hydroelectric facility operation. Trans. Am. Fish. Soc. 125, 66-67.

Auer, N. A., 1996b: Importance of habitat and migration to sturgeons with emphasis on lake sturgeon. Can. J. Fish. Aquat. Sci. 53, 152 160

Auer, N. A., 1999: Population characteristics and movements of lake sturgeon in the Sturgeon River and Lake Superior. J. Great Lakes Res. 25, 282-293.

Auer, N. A., 2004: Conservation. In: Sturgeons and paddlefish of North America. G. T. O. LeBreton, F. W. H. Beamish, R. S. McKinley (Eds). Dordrecht, the Netherlands, pp. 252-276.

Brousseau, C. S., 1987: The lake sturgeon (Acipenser fulvescens) in Ontario. In: C. H. Olver, (Ed.). Proc. Workshop on the lake sturgeon (Acipenser fulvescens), On. Fish. Tech. Rep. Series No. 23, Maple.

Bruch, R. M.; Compana, S. E.; Davis-Foust, S. L.; Hansen, M. J.; Janssen, J., 2009: Lake sturgeon age validation using bomb radiocarbon and known age fish. Trans. Am. Fish. Soc. 138, 361372.

Fitzpatrick, M. S.; Redding, J. M.; Ratti, F. D.; Scheck, C. B., 1987: Plasma testosterone predicts the ovulatory response of coho salmon (Oncorhynchus kisutch) to gonadotropin-releasing hormone analog. Can. J. Fish. Aquat. Sci. 44, 1351-1357.

Fortin, R.; Dumont, P.; Guenette, S., 1996: Determinants of growth and body condition of lake sturgeon (Acipenser fulvescens). Can. J. Fish. Aquat. Sci. 53, 1150-1156.

Goldman, C. R., 1988: Primary productivity, nutrients, and transparency during the early onset of eutrophication in ultra-oligotrophic Lake Tahoe, California-Nevada. Limnol. Oceanogr. 33, 13211333.

Goldman, C. R.; de Amazaga, E., 1984: Primary productivity and precipitation at Castle Lake and Lake Tahoe during twenty-four years, 1959-1982 Verhandlung Internat. Ver. Limnologie. 22, 591-599.

Harkness, W. J. K., Dymond, J. R., 1961: The lake sturgeon: The history of its fishery and problems of conservation. Ontario Department of Lands, Forest.

Hay-Chmielewski, E. M., 1987: Habitat preferences and movement patterns of the lake sturgeon (Acipenser fulvescens) in Black Lake, Michigan. Mich. Dept. Nat. Res. Fish. Res. Rep. No. 1949.

Hosmer, D. W., Jr; Lemeshow, S., 1989: Applied Logistic Regression. Wiley, New York.

Kallemeyn, L. W.; Holmberg, K. L.; Perry, J. A.; Odde, B. Y., 2003: Aquatic synthesis for voyageurs national park. US Geol. Surv. Info. Tech. Rep. 2003-0001.

Khoroshko, P. N., 1972: The amount of water in the Volga Basin and its effect on the reproduction of sturgeons (Acipenseridae) under conditions of normal and regulated discharge. J. Ichthyol. 12, 608-616.

Kohlhorst, D. W.; Botsford, L. W.; Brennan, J.; Cailliet, G. M., 1991: Aspects of the structure and dynamics of an exploited central
California population of white sturgeon (Acipenser transmontanus). In: Actes du premier colloque international sur les sturgeon. P. Williot (Ed.). Cemagref, Groupement de Bourdeaux, Gazinet, France, pp. 277-294.

Lebreton, G. T.; Beamish, F. W., 2004: Growth, bioenergetics, and age. In: Sturgeons and paddlefish of North America. G. T. O LeBreton, F. W. H. Beamish, R. S. McKinley (Eds). Dordrecht, the Netherlands, pp. 217-230.

Maceina, M. J., 2003: Verification of the influence of hydrologic factors on crappie recruitment in Alabama reservoirs. North Am. J. Fish. Manag. 23, 470-480.

Maceina, M. J.; Pereira, D. L., 2007: Recruitment. In: Analysis and interpretation of freshwater fisheries data. C. S. Guy, M. L. Brown (Eds). American Fisheries Society, Bethesda, MD, pp. 121-185.

Magnuson, J. J.; Benson, B. J.; Kratz, T. K., 1990: Temporal coherence in the limnology of a suite of lakes in Wisconsin, USA. Freshwater Biol. 23, 145-159.

McCombie, A. M., 1959: Some relations between air temperatures and the surface water temperatures of lakes. Limnol. Oceanogr. 3, $252-258$.

McLeod, D., 1999: An assessment of lake sturgeon populations in the lower Seine River system, Ontario 1993-1995. Ont. Minist. Nat. Resour., Fort Frances District Rep. Series No. 43, Fort Frances, ON.

McLeod, D., 2008: A population assessment of lake sturgeon in the Namakan River, Ontario 2006-2008. Ont. Minist. Nat. Resour., Fort Frances District Report Series No. 81.

McLeod, D.; Debruyne, C., 2009: Movement and seasonal distribution of lake sturgeon in the Namakan River, Ontario. Preliminary Report 2007-2008. Ont. Minist. Nat. Resour., Fort Frances District Report Series No. 82.

Miranda, L. E.; Bettoli, P. W., 2007: Mortality. In: Analysis and interpretation of freshwater fisheries data. C. S. Guy, M. L. Brown (Eds). American Fisheries Society, Bethesda, MD, pp. 229-278.

Mosindy, T.; Rusak, J., 1991: An assessment of lake sturgeon populations in Lake of the Woods and the Rainy River 19871990. Ont. Minist. Nat. Resour., Lake of the Woods Fisheries Assessment Unit Report 1991:01, Toronto, ON.

Nikol'skaya, N. G.; Sytina, L. A., 1978: A comparative analysis of the action of constant temperatures on the embryonic development of four species of sturgeon. J. Ichthyol. 18, 86-100.

Nilo, P.; Dumont, P.; Fortin, R., 1997: Climatic and hydrological determinants of year-class strength of St. Lawrence River lake sturgeon (Acipenser fulvescens). Can. J. Fish. Aquat. Sci. 54, 774 780 .

Power, M.; McKinley, R. S., 1997: Latitudinal variation in lake sturgeon size as related to thermal opportunity for growth. Trans. Am. Fish. Soc. 126, 549-558.

Priegel, G. R.; Wirth, T. L., 1978: Lake sturgeon populations, growth, and exploitation in lakes Poygan, Winneconne, Lake Butte Des Morts, Wisconsin. Wis. Dep. Nat. Resour. Tech. Bull. No. 107.

Probst, R. T.; Cooper, E. L., 1955: Age, growth, and production of the lake sturgeon (Acipenser fulvescens) in Lake Winnebago region, Wisconsin. Trans. Am. Fish. Soc. 84, 207-227.

Rich, C. F., Jr; McMahon, T. E.; Rieman, B. E.; Thompson, W. L., 2003: Local-habitat, watershed, and biotic features associated with bull trout occurrence in Montana streams Trans. Am. Fish. Soc. 132, 1053-1064

Richmond, A. M.; Kynard, B., 1995: Ontogenetic behavior of shortnose sturgeon, Acipenser brevirostrum Copeia 1, 172-182

SAS $\subset$ Institute Inc 1999: SAS language reference: dictionary, version 8. SAS Institute Inc Cary, NC

Scott, W. B.; Crossman, E. J., 1998: Freshwater fishes of canada. 4th edn Galt House Publications, Oakville, Ontario

Shuter, B. J.; Post, J. R., 1990: Climate, population viability, and the zoogeography of temperate fishes Trans. Am. Fish. Soc. 119, 314 336

Slipke, J. W.; Maceina, M. J., 2000: Fishery analyses and simulation tools (FAST) version 20 Auburn University, Auburn, Alabama (available from the American Fisheries Society at http://www. fisheriesorg/cus/cuslib/htm)

Stewig, J. D.; 2005: A population assessment of the lake sturgeon in Lake of the Woods and the Rainy River, 2004. Min Dep Nat Resour Division of Fisheries Completion Rep F-29-R(P)-24

Threader, R. W.; Brousseau, C. S., 1986: Biology and management of the lake sturgeon in the Moose River, Ontario North Am. J. Fish. Manage. 6, 383-390 
Votinov, N. P.; Kas'yanov, V. P., 1978: The ecology and reproductive efficiency of the Siberian sturgeon, Acipenser baeri, in the $\mathrm{Ob}$ as affected by hydraulic engineering works J. Ichthyol. 18, 20-29

Webb, M. A. H.; Erickson, D. L., 2007: Reproductive structure of the adult green sturgeon, Acipenser medirostris, population in the Rogue River, Oregon Environ. Biol. Fishes. 79, 305-314

Webb, M. A. H.; Fiest, G. W.; Schreck, C. B.; Foster, E. P.; Fitzpatrick, M. S., 2002: Potential classification of sex and stage of gonadal maturity of wild white sturgeon using blood plasma indicators Trans. Am. Fish. Soc. 131, 132-142

Author's address: Stephanie Shaw, Fisheries and Aquatic Sciences, University of Florida, 7922 NW 71st St, Gainesville, FL 32608, USA

E-mail: slshaw@ufledu 